\title{
Addressing the development of both knowledge and clinical reasoning in nursing through the perspective of script concordance: An integrative literature review
}

\author{
Marie-France Deschênes , Johanne Goudreau \\ Faculty of Nursing, Université de Montréal, Montreal, Canada
}

Received: May 8, 2017

DOI: $10.5430 /$ jnep.v7n12p28

\author{
Accepted: July 5, 2017 \\ Online Published: July 17, 2017 \\ URL: https://doi.org/10.5430/jnep.v7n12p28
}

\begin{abstract}
Background: In clinical practice settings, where situations of uncertainty exist, clinical reasoning is situated or contextualized. It calls upon honed knowledge, wherein nurses rely on highly-developed and organized knowledge networks known as "mental scripts".

Methods: The aim of this integrative literature review was to address ways to develop knowledge and clinical reasoning in nursing through the use of mental scripts, and to tackle these pedagogical considerations. The literature search was performed using the following data sources: CINHAL, MEDLINE Google Scholar, PubMed, ProQuest, PsycINFO, Scopus and Web of Science.

Results: Script concordance, which optimises situated clinical reasoning, ties in with the socio-cognitive perspective of cognitive apprenticeship, using role models to guide the development of knowledge and clinical reasoning in nursing. Moreover, this perspective proposes implementing new teaching strategies, which focus on situational awareness, reflective acuity, and cognitive dialogue.

Conclusions: The perspective of script concordance allows a foreseeable innovative formulation of practices favourable to the development of clinical reasoning in nursing.
\end{abstract}

Key Words: Nursing clinical reasoning, Script theory, Teaching strategies, Literature review, Nursing education, Schemas

\section{INTRODUCTION}

One of the current challenges educational institutions are facing is the development and planning of pedagogical activities to promote the optimal development of knowledge and clinical reasoning, since making decisions in complex and uncertain conditions has become the norm in current clinical nursing practice. ${ }^{[1]}$ This reality places newly graduated nurses in situations where they need immediate capacity for sound clinical reasoning, from the very beginning of their career. A gap in clinical reasoning because of inadequate training during initial education can lead to the risk of er- rors and consequently affects the quality and safety of the care provided to patients. ${ }^{[2,3]}$ In this context, it is therefore necessary to reassess the quality of the pedagogical support provided and to adapt, among other elements, educational activities by bridging the gap between education and practice with regard to clinical reasoning in nursing. ${ }^{[1]}$ Clinical reasoning, a competency at the heart of nursing practice, is characterised by recursive metacognitive and cognitive processes mobilised by nurses. ${ }^{[4,5]}$ In clinical practice settings, where situations of uncertainty exist, clinical reasoning is situated or contextualized. It calls upon honed knowledge, wherein

\footnotetext{
*Correspondence: Marie-France Deschênes; Email: marie-france.deschenes@umontreal.ca; Address: Faculty of Nursing, Université de Montréal, C. P. 6128, succ. Centre-Ville, Montréal, QC, H3C 3J7, Canada.
} 
nurses rely on highly-developed and organized knowledge networks known as "mental scripts",[6,7] to solve clinical problems. But how can scripts contribute to the development of nursing knowledge, and subsequently to the development of clinical reasoning in nursing? How can we apply this theoretical knowledge in an educational setting to have a tangible impact on clinical reasoning in actual nursing practice?

This literature review proposes the study of cognitive script theory in nursing education as a way to address these questions. It further proposes a theoretical design for the implementation of new teaching strategies congruent with cognitive processes mobilised and associated with clinical reasoning in situations actually encountered in professional nursing practice.

\section{Context}

How is knowledge developed and encoded in long-term memory? Through which indicators in everyday life do individuals recognize the key elements of their environment? What are the mental representations that enable them to react appropriately to a situation? These questions serve as the foundation for the development of information processing and cognitive mapping theories, which led to the development of script theory in the late 70 's. ${ }^{[6,7]}$ From this perspective of cognitive psychology, individuals do not process various life situations in a cognitive vacuum. They react to a situation in a way that seems most pertinent given their experiential baggage, memorized as models or mental representation schemas. ${ }^{[7]}$ This propensity to use mental representations helps individuals recognize situations they have already experienced, to interpret and to predict events, and consequently to act intuitively. A script is therefore defined as a mental representation schema that allows for the stereotyping of different information into units of meaning associated with a situation. ${ }^{[6,7]}$ These mental representations allow individuals to assess the presence or absence of concordance of a prototypical given presentation as a way to weigh and predict subsequent data that emerges from it, ${ }^{[8]}$ and to act accordingly in order to live and survive in their environment.

A script refers to associative networks and the development of causal links between elements of knowledge that guide the selection of information, its interpretation, and its memorisation. ${ }^{[9-11]}$ For its part, the concept of illness scripts first appeared in the medical literature during the 80's. This concept describes the structure of professional knowledge and its link to the wealth and quality of the professional knowledge that one develops and organizes over time. Thus, whereas knowledge is reduced and dispersed in students and novices respectively, in experts, knowledge is compiled and organized. ${ }^{[12,13]}$ Faced with a clinical situation, experts quickly formulate hypotheses through the activation of scripts. These scripts are generated by an automatic, iterative, and relatively unconscious thought process ${ }^{[13]}$ where experts systematically assess causal and event-related characteristics, as well as the future consequences of a health problem. ${ }^{[9,14]}$ In other words, experts reason by having a hypothesis in mind, and all the subsequent data obtained is interpreted in order to nuance, reject or reinforce the formulated hypothesis. ${ }^{[15]}$ What experts seek to uncover is whether the current situation bears the same characteristics than that of its usual representation, as mapped by their scripts. ${ }^{[9,16]}$ It is important to clarify that experts also develop back-up potential hypotheses and that the recursive exercise of clinical reasoning leads to the confrontation and hierarchizing of these hypotheses. ${ }^{[16,17]}$ Their reasoning also relies on a situational awareness of the key elements of a health problem. Thus, clinical reasoning relies on a wealth of professional knowledge developed over the years, which is quickly retrievable, as well as on more deliberate reflections on professional practice. ${ }^{[18,19]}$

In light of this, how can script theory contribute to knowledge development in nursing students? How can this theory usher in the implementation of teaching strategies pertinent to the development of clinical reasoning in nursing?

\section{THE REVIEW}

\subsection{Objective}

This literature review aims to answer the following research questions: How can script theory contribute to the development of nursing knowledge? How can we apply this theoretical knowledge in an educational setting to have a tangible impact on clinical reasoning in nursing?

\subsection{Method}

This is an integrative literature review ${ }^{[20]}$ that aims to tackle a conceptual reflection on a way to address the development of knowledge integrated into clinical reasoning in nursing through the perspective of mental scripts. An integrative review is a method used to summarize knowledge, combining both theoretical writings and empirical studies, in order to develop a better understanding of a particular phenomenon or theme. ${ }^{[21-23]}$ This method specifically contributes to the development of theoretical concepts that can be applied in terms of policies and practices within the field. ${ }^{[23,24]}$ This summary allows us to consider the theoretical implications of scripts in nursing education.

\subsection{Research strategy and data extraction}

The literature search was conducted between 2016-07-01 and 2017-03-01 using the following data sources: CINHAL, MEDLINE, Google Scholar, PubMed, ProQuest, PsycINFO, 
Scopus and Web of Science, using the following keywords and descriptors [(1) Diagnostic Reasoning, Diagnosis Differential, Nursing Diagnosis, Thinking, Critical Thinking, Decision Making, Decision Making Clinical, Decision Support Techniques, Intuition, Judgment, Cognition, Mental Processes, Cues, Recognition (Psychology); Problem Identification, Problem Solving, Clinical reasoning], [(2): Theory, Theory-Practice Relationship+, Theory Validation, Nursing Theory, Psychometrics, Measurement Issues and Assessments, Psychological Tests, Clinical Assessment Tools, Nursing Assessment, Educational Measurement, Process Assessment (Health Care), Competency Assessment, Student Performance Appraisal, Scripts, Script concordance test (SCT)], [(3):Education, Nursing+, Students, Nursing+]. The Boolean operator "OR" was used for terms within the same category, whereas "AND" was used to combine different categories.

Faced with the exhaustive nature of the literature reviewed, the selection of studies was guided by the following research questions and criteria: 1- empirical studies in the field of nursing specifically focused on script theory; 2- literature written in French or in English; and 3- literature published since 2010 in order to obtain a contemporary view of the pedagogical changes to develop in nursing education. ${ }^{[1]}$ Other data sources, sometimes pre-dating 2010, were added following a search of the references of the literature reviewed (backward search) and by doing a search for papers that cited data sources considered relevant (forward search). A first preselection, based on the title and abstract, was conducted by the principal author (MFD), followed by a more in-depth review of the selected articles. This process allowed for the removal of articles that did not respond to the aim of this summary. Removal was justified by the following reasons: 1- the term script used in a non-theoretical perspective, for example, in the context of computer programing language, and 2- the absence of empirical data. Every study read and considered compatible with the above-stated aim was added to a literature review presenting the various data to facilitate critical analysis. A second reviewer, the author of this summary (JG), confirmed this analysis. The flow chart (see Figure 1) presents the studies chosen, fourteen (14) of which proved useful in answering the research questions.

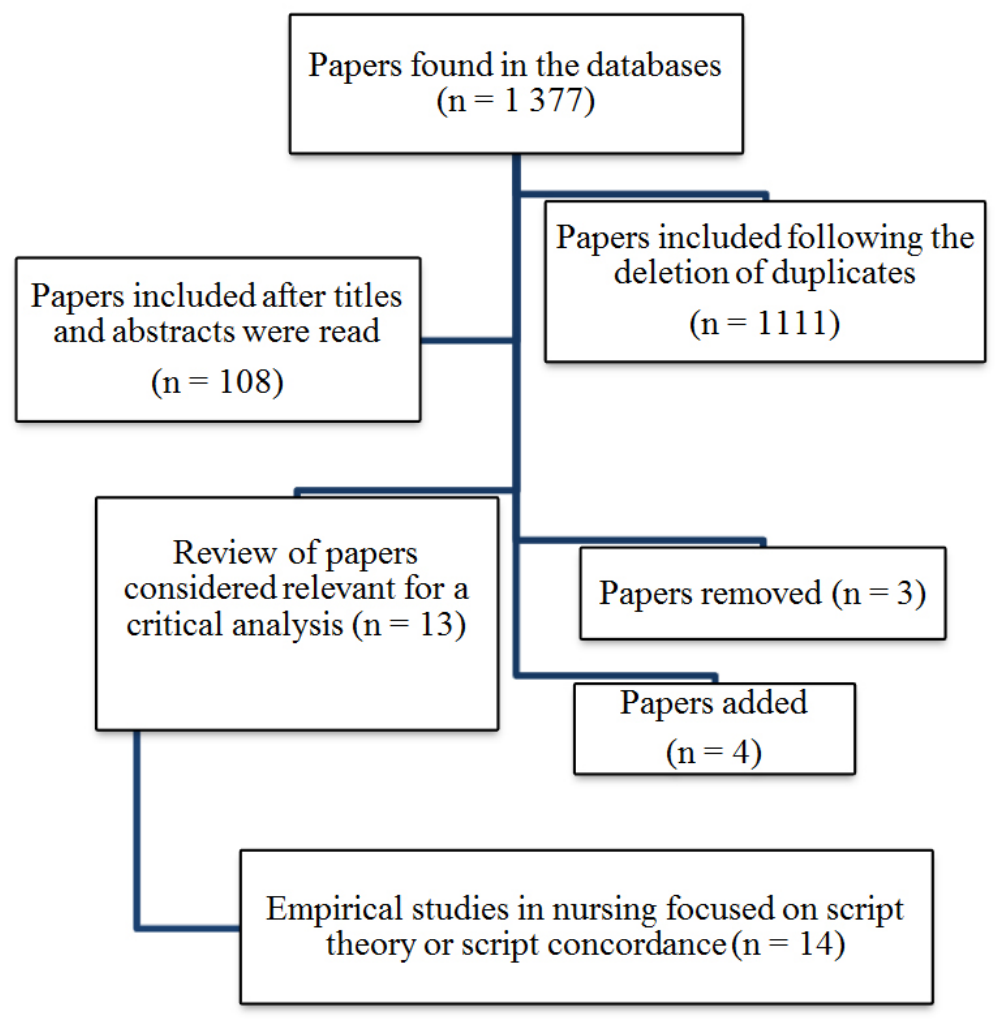

Figure 1. Flow chart

\section{Results}

This literature review aims to answer the following research questions: How can script theory contribute to the development of nursing knowledge? How can we apply this theoret- ical knowledge in an educational setting to have a tangible impact on clinical reasoning in nursing? To answer these questions, fourteen studies were reviewed and analysed. Four of these rely on a qualitative method (see Table 1), whereas 
ten use a quantitative method (see Table 2). The presentation of the findings summarizes how script theory enables the understanding of the complex and continued development of knowledge and clinical reasoning in nursing. The formative assessment of clinical reasoning in nursing through script concordance demonstrates the usefulness of this perspective as a teaching strategy to develop this competency.

Table 1. Qualitative studies

\begin{tabular}{|c|c|c|c|c|}
\hline $\begin{array}{l}\text { Authors, date, } \\
\text { country }\end{array}$ & Aim & Methodology & Sample & Main results and limitations \\
\hline $\begin{array}{l}\text { Dumont, Loye and } \\
\text { Goudreau } \\
(2015)^{[25]} \\
\text { Canada }\end{array}$ & $\begin{array}{l}\text { Explore the } \\
\text { possibility of } \\
\text { using SCT } \\
\text { questions as a tool } \\
\text { to assess CRN }\end{array}$ & $\begin{array}{l}\text { Think aloud method used to } \\
\text { respond to presented SCT } \\
\text { scenarios }{ }^{[26]} \\
\text { Identifying and coding } \\
\text { cognitive strategies according to } \\
\text { Fonteyn (1998) }\end{array}$ & $\begin{array}{l}\text { Expert nurses } \\
(\mathrm{n}=14) \text { and } \\
\text { students } \\
\mathrm{s}(\mathrm{n}=55)\end{array}$ & $\begin{array}{l}\text { Various cognitive strategies are used in terms of } \\
\text { CRN according to the level of expertise } \\
\text { Few or no hypotheses are formulated by students } \\
\text { The SCT could help identify strengths and } \\
\text { weaknesses in nursing students }\end{array}$ \\
\hline $\begin{array}{l}\text { Goudreau, Boyer } \\
\text { and Létourneau } \\
(2014)^{[5]} \\
\text { Canada }\end{array}$ & $\begin{array}{l}\text { Formulate a } \\
\text { cognitive learning } \\
\text { model of CRN } \\
\text { (Clinical } \\
\text { reasoning in } \\
\text { nursing) }\end{array}$ & $\begin{array}{l}\text { Think aloud method used to } \\
\text { respond to presented SCT } \\
\text { scenarios }{ }^{[26]} \\
\text { Identifying and coding } \\
\text { cognitive strategies according to } \\
\text { Fonteyn (1998) }\end{array}$ & $\begin{array}{l}\text { Three groups } \\
\text { 1- Students }(\mathrm{n}= \\
41), 2 \text { - newly } \\
\text { graduated } \\
\text { nurses }(\mathrm{n}=11) \text {, } \\
\text { and 3- expert } \\
\text { nurses }(\mathrm{n}=14)\end{array}$ & $\begin{array}{l}\text { The cognitive model describes the } \\
\text { developmental stages of a competency from the } \\
\text { beginning of its development to clinical expertise } \\
\text { Few or no hypotheses are formulated by } \\
\text { students. This is also observed in a few nurses } \\
\text { CRN expertise is developed through critical } \\
\text { appropriation of treatment protocols and routines } \\
\text { rather than through practice centered on tasks. }\end{array}$ \\
\hline $\begin{array}{l}\text { Greenwood, } \\
\text { Sullivan, Spence, } \\
\text { et al. (2000) } \\
\text { Australia }\end{array}$ & $\begin{array}{l}\text { Explore changes } \\
\text { in CRN }\end{array}$ & $\begin{array}{l}\text { Think aloud technique used to } \\
\text { generate verbal reports, during } \\
\text { and after care interventions, } \\
\text { through semi-structured } \\
\text { interviews } \\
\text { Descriptive analysis of the data }\end{array}$ & $\begin{array}{l}\text { Neonatal nurses } \\
(\mathrm{n}=4)\end{array}$ & $\begin{array}{l}\text { Highlights the use of scripts in the CRN process } \\
\text { In a complex and ambiguous situation in nursing } \\
\text { practice, scripts are activated, but environmental } \\
\text { context considerably influences CRN }\end{array}$ \\
\hline $\begin{array}{l}\text { Offredy and } \\
\text { Meerabeau } \\
\text { (2005) } \\
\text { England }\end{array}$ & $\begin{array}{l}\text { Explore the } \\
\text { cognitive } \\
\text { processes used by } \\
\text { nurse practitioners } \\
\text { and general } \\
\text { practitioners }\end{array}$ & $\begin{array}{l}\text { Think aloud technique used by } \\
\text { participants during the } \\
\text { presentation of six written } \\
\text { patient scenarios } \\
\text { Descriptive analysis of the data }\end{array}$ & $\begin{array}{l}\text { Nurse } \\
\text { practitioners } \\
(\mathrm{n}=11) \text { and } \\
\text { general } \\
\text { practitioners } \\
(\mathrm{n}=11)\end{array}$ & $\begin{array}{l}\text { Nurses as well as doctors use mental } \\
\text { representation schemas, scripts, during } \\
\text { decision-making } \\
\text { Information processing theory and the "think } \\
\text { aloud" technique are useful in identifying errors } \\
\text { in the decision-making process and could be } \\
\text { used as teaching tools }\end{array}$ \\
\hline
\end{tabular}

\subsection{The role of script theory in the process of clinical reasoning in nursing}

The perspective of the contribution of script theory to the non-analytical process of reasoning in nursing was described in the 2000s by Greenwood, Sullivan, Spence (2000). ${ }^{[28]}$ Often identified as "pattern recognition" in the scientific literature, this mode of reasoning refers to the intuitive, even relatively unconscious, use of scripts. Through these patterns, the interpretation of a situation is quickly linked to professional experiences that act as blueprints to understand the situation. In other words, scripts are spontaneously activated in nurses; they are strongly associated with situational awareness and clinical action. Therefore, we can observe that nurses do not approach a situation in a cognitive vacuum, but rather they activate clinical nursing reasoning through a complex cognitive exercise involving the continued and repeated validation of their hypotheses. It is through the analysis of the verbal reports of the thoughts of nurses $(n=$
4) working in a neonatal intensive care unit that Greenwood, Sullivan, Spence (2000) ${ }^{[28]}$ also discovered certain inconsistencies between what nurses think they should do and the influence of the workplace culture in their reasoning process. Thus, there seems to be a certain "competition" between the different kinds of knowledge developed in nurses: the environmental context isn't simply background noise during the clinical reasoning process; rather it contributes to shaping it. The study by Offredy and Meerabeau (2005) ${ }^{[29]}$ is in the same vein. The objective of this study was to explore the cognitive processes used by nurses and general practitioners. The authors reiterate the fact that health professionals use mental representation schemas in clinical decision-making. They highlight script theory and the think aloud technique as useful and relevant pedagogical tools that can help identify potential errors in the decision-making process of health professionals. 
Table 2. Quantitative studies

\begin{tabular}{|c|c|c|c|c|}
\hline $\begin{array}{l}\text { Authors, date, } \\
\text { country }\end{array}$ & Aim & Methodology & Sample & Results \\
\hline $\begin{array}{l}\text { Borges } \\
(2016)^{[30]} \\
\text { Portugal }\end{array}$ & $\begin{array}{l}\text { Develop and validate } \\
\text { SCT scenarios to asses } \\
\text { reasoning in the } \\
\text { dimension of } \\
\text { management in nursing }\end{array}$ & $\begin{array}{l}\text { Statistical analysis of } \\
\text { psychometric properties of } \\
\text { the SCT }\end{array}$ & $\begin{array}{l}\text { Students }(\mathrm{n}=50) \text { and } \\
\text { a panel of experts } \\
(\mathrm{n}=14)\end{array}$ & $\begin{array}{l}\text { The SCT demonstrated an excellent reliability index: }(\alpha: 0.95) \\
\text { Number of items on the SCT: } 100 \\
\text { Differences were noted between scores obtained by students } \\
(65.97 \pm 10.46) \text { and by experts }(77.06 \pm 6.70)\end{array}$ \\
\hline $\begin{array}{l}\text { Côté, Tanguay, } \\
\text { Gagnon } \\
(2014)^{[31]} \\
\text { Canada }\end{array}$ & $\begin{array}{l}\text { Develop and validate } \\
\text { SCT scenarios to asses } \\
\text { CRN in a context of } \\
\text { clinical deterioration }\end{array}$ & $\begin{array}{l}\text { Statistical analysis of } \\
\text { psychometric properties of } \\
\text { the SCT }\end{array}$ & $\begin{array}{l}\text { Students }(\mathrm{n}=47) \text { and } \\
\text { a panel of experts } \\
(\mathrm{n}=21)\end{array}$ & $\begin{array}{l}\text { The SCT demonstrated a good reliability index: }(\alpha: 0.76) \\
\text { Number of items on the test: } 68 \\
\text { A significant positive linear relationship was observed between } \\
\text { the scores and clinical expertise }(p<.05) \\
\text { Limitation: Removal of } 2 \text { experts from the reference panel }\end{array}$ \\
\hline $\begin{array}{l}\text { Dawson et al. } \\
(2014)^{[41]} \\
\text { United States }\end{array}$ & $\begin{array}{l}\text { Validate SCT scenarios } \\
\text { to assess human caring, } \\
\text { a dimension of CRN }\end{array}$ & $\begin{array}{l}\text { Statistical analysis of } \\
\text { psychometric properties of } \\
\text { the SCT }\end{array}$ & $\begin{array}{l}\text { Students }(n=48) \text { and } \\
\text { a panel of experts } \\
(n=13)\end{array}$ & $\begin{array}{l}\text { The SCT demonstrated a good reliability index: }(\alpha: 0.86) \\
\text { Number of items on the SCT: } 73 \\
\text { A statistically significant difference was observed between the } \\
\text { scores of the novices ( } 62.71 \pm 8.5 \text { ) and those of the experts } \\
\text { ( } 78.52 \pm 8.09 \text { ) } \\
\text { Limitation: Possible problem with the accuracy of the content } \\
\text { due to the translation of the SCT from the original study by } \\
\text { Deschênes, Charlin, Gagnon, et al. (2011) }{ }^{[26]}\end{array}$ \\
\hline $\begin{array}{l}\text { Deschênes et al. } \\
(2011)^{[26]} \\
\text { Canada }\end{array}$ & $\begin{array}{l}\text { Develop and validate } \\
\text { SCT scenarios to } \\
\text { assess human caring, a } \\
\text { dimension of CRN }\end{array}$ & $\begin{array}{l}\text { Statistical analysis of } \\
\text { psychometric properties of } \\
\text { the SCT }\end{array}$ & $\begin{array}{l}\text { Students }(\mathrm{n}=30) \text { and } \\
\text { a panel of experts } \\
(\mathrm{n}=12)\end{array}$ & $\begin{array}{l}\text { The SCT demonstrated a good reliability index: }(\alpha: 0.86) \\
\text { Number of items on the SCT: } 73 \\
\text { A statistically significant difference was observed }(p<.01) \\
\text { between the scores of the novices ( } 53.3 \pm 7.2) \text { and those of the } \\
\text { experts ( } 61.6 \pm 3.1 \text { ) } \\
\text { Limitation: Removal of } 3 \text { experts from the reference panel }\end{array}$ \\
\hline $\begin{array}{l}\text { Devlin, } \\
\text { Marquis, Riker } \\
(2008)^{[22]} \\
\text { United States }\end{array}$ & $\begin{array}{l}\text { Measure the impact of } \\
\text { an educational } \\
\text { intervention based on } \\
\text { SCT scenarios on the } \\
\text { clinical identification } \\
\text { of delirium episodes in } \\
\text { conjunction with an } \\
\text { assessment scale }\end{array}$ & $\begin{array}{l}\text { Measure the efficiency of } \\
\text { nurses in evaluating the } \\
\text { presence of delirium, pain, } \\
\text { and level of sedation before } \\
\text { and after an educational } \\
\text { intervention, which included } \\
\text { two SCT case scenarios }\end{array}$ & $\begin{array}{l}\text { Intensive care unit } \\
\text { nurses }(\mathrm{n}=50)\end{array}$ & $\begin{array}{l}\text { Following the educational intervention, the number of nurses } \\
\text { who were able to efficiently assess delirium significantly } \\
\text { increased ( } p<.0005) \\
\text { The educational intervention based on the use of SCT scenarios } \\
\text { improves the ability to detect the early signs of delirium }\end{array}$ \\
\hline $\begin{array}{l}\text { Gilbert } \\
(2015)^{[33]} \\
\text { Canada }\end{array}$ & $\begin{array}{l}\text { Develop and evaluate a } \\
\text { SCT to measure CRN } \\
\text { regarding the optimal } \\
\text { use of medication in } \\
\text { long-term care } \\
\text { facilities }\end{array}$ & $\begin{array}{l}\text { Statistical analysis of } \\
\text { psychometric properties of } \\
\text { the SCT }\end{array}$ & $\begin{array}{l}\text { Nursing students }(\mathrm{n}= \\
76) \text { and expert nurses } \\
(\mathrm{n}=10)\end{array}$ & $\begin{array}{l}\text { The SCT demonstrates an average reliability index: }(\alpha: 0.65) \\
\text { Number of items on the SCT: } 55 \\
\text { A statistically significant difference was observed }(p<.02) \\
\text { between the scores of novices }(55.6 \pm 7.7) \text { and those of experts } \\
(63.7 \pm 8.0) \\
\text { Limitation: Removal of } 1 \text { expert from the reference panel }\end{array}$ \\
\hline $\begin{array}{l}\text { Latreille } \\
(2012)^{[34]} \\
\text { Canada }\end{array}$ & $\begin{array}{l}\text { Evaluate CRN in } \\
\text { pediatrics, using a SCT }\end{array}$ & $\begin{array}{l}\text { Statistical analysis of } \\
\text { psychometric properties of } \\
\text { the SCT }\end{array}$ & $\begin{array}{l}3^{\text {rd }} \text { year students }(n= \\
30) \text {; floating staff } \\
\text { nurses }(n=40) \text {, and } \\
\text { expert paediatric } \\
\text { nurses }(n=15)\end{array}$ & $\begin{array}{l}\text { The SCT demonstrates an average reliability index: ( } \alpha \text { : } 0.61) \\
\text { Number of items on the SCT: } 36 \\
\text { A statistically significant difference was observed between the } \\
\text { scores of students (average score: } 62.3 \% \text { ) and those of experts } \\
\text { (average score: } 77.4 \%)(p<.01) \text {, but not between those of } \\
\text { nurses (average score: } 75 \%) \text { and experts }\end{array}$ \\
\hline $\begin{array}{l}\text { Pintz (2006) }{ }^{[35]} \\
\text { United States }\end{array}$ & $\begin{array}{l}\text { Evaluate the } \\
\text { psychometric } \\
\text { properties of the } \\
\text { Diagnostic Reasoning } \\
\text { Assessment (DRA), a } \\
\text { CRN assessment } \\
\text { instrument }\end{array}$ & $\begin{array}{l}\text { Statistical generalizability } \\
\text { analyses of CRN measures } \\
\text { using three instruments: the } \\
\text { DRA, the SCT and the } \\
\text { Subjective, objective, } \\
\text { assessment and plan (SOAP) } \\
\text { Note Evaluation Tool }\end{array}$ & $\begin{array}{l}\text { Graduate level nurse } \\
\text { practitioner students } \\
(\mathrm{n}=50)\end{array}$ & $\begin{array}{l}\text { The generalizability coefficient }\left(\rho^{2}\right) \text { of the SCT is } 0.59 \text { with } 30 \\
\text { items } \\
\text { It is suggested to increase the number of items to ensure a better } \\
\text { reliability measure of the instrument } \\
\text { The SCT mainly measures the knowledge that contributes to } \\
\text { the use of CRN }\end{array}$ \\
\hline $\begin{array}{l}\text { Sadhuwong, } \\
\text { Koraneekij and } \\
\text { Natakuatoong } \\
(2016)^{[36]} \\
\text { Thailand }\end{array}$ & $\begin{array}{l}\text { Examine the effects of } \\
\text { a teaching strategy } \\
\text { integrating multimedia } \\
\text { lessons on the } \\
\text { development of CRN }\end{array}$ & $\begin{array}{l}\text { Quasi-experimental study } \\
\text { CRN measured by a SCT } \\
\text { following an educational } \\
\text { multimedia intervention }\end{array}$ & $\begin{array}{l}\text { Students }(\mathrm{n}=56) \\
\text { divided into an } \\
\text { experimental group } \\
(\mathrm{n}=28) \text { and a control } \\
\text { group }(\mathrm{n}=28)\end{array}$ & $\begin{array}{l}\text { The post-test score of the experimental group was significantly } \\
\text { higher than the pre-test score }(p<.001) \text {. The post-test score of } \\
\text { the experimental group was significantly higher than the } \\
\text { control group ( } p<.05) \\
\text { Self-directed learning and critical thinking must be stimulated } \\
\text { in programs }\end{array}$ \\
\hline $\begin{array}{l}\text { Tapaneeyakorn, } \\
\text { Kosolchuen- } \\
\text { vijit, Anonrath, } \\
(2016)^{[37]} \\
\text { Thailand }\end{array}$ & $\begin{array}{l}\text { Measure and compare } \\
\text { the level of CRN } \\
\text { competence } \\
\text { Explore the factors that } \\
\text { influence CRN }\end{array}$ & $\begin{array}{l}\text { Descriptive comparative } \\
\text { study using 1- questionnaires } \\
\text { to identify the characteristics } \\
\text { of participants, and } 2 \text { - a SCT }\end{array}$ & $\begin{array}{l}2^{\text {nd }}, 3^{\text {rd }} \text {, and } 4^{\text {th }} \text { year } \\
\text { students }(n=56)\end{array}$ & $\begin{array}{l}\text { Fourth year students obtained the highest score on the CRN } \\
\text { assessment (average score: } 60.32 \% \text { ) } \\
\text { The predictive factors of CRN were the average of the } \\
\text { cumulated results, age, and the students' open-mindedness ( } r= \\
0.395, p<.01 \text { ) }\end{array}$ \\
\hline
\end{tabular}


The development of expertise linked to clinical reasoning in nursing relies on a repertoire of professional knowledge developed and supported by professional experiences. ${ }^{[5]}$ In this regard, researchers focused on determining whether the evaluation of script concordance between students, novices and experts could distinguish the level of expertise associated with clinical reasoning in nursing. This is what inspired studies to investigate the assessment of clinical reasoning in nursing though script concordance, using a measuring instrument: the SCT.

\subsection{Assessment of clinical reasoning in nursing through script concordance}

The use of the SCT provided insight into the use of an instrument to measure clinical reasoning and its contribution to health science education, including nursing. Initially developed in the field of medicine by Charlin (2002) ${ }^{[38]}$ and based on script theory, the SCT is a test presenting several clinical cases to students. The scenarios, which focus on ill-defined problems, aim to assess clinical reasoning in ambiguous or uncertain situations, illustrating professional situations that can occur in daily practice. ${ }^{[39,40]}$ Since it addresses ill-defined problems and activates procedural knowledge in decision-making, the SCT helps determine whether knowledge is compiled and organized, rather than simply accumulated. In a way, the SCT captures the key elements associated with reasoning mobilised in the context of a real-world situation that can occur in professional practice. Experts complete the test individually and without reaching consensus before administering it to students. Thus, the SCT assesses whether the multiple decisions made by students during their reasoning process are in line with the decisions taken by a panel of experts in the field, ${ }^{[39]}$ giving this instrument its name, concordance test (see Figure 2).

Mr. Smith is admitted to the ER. Following an initial assessment, you note that Mr. Smith exhibits several behaviours that could potentially endanger his health and safety.

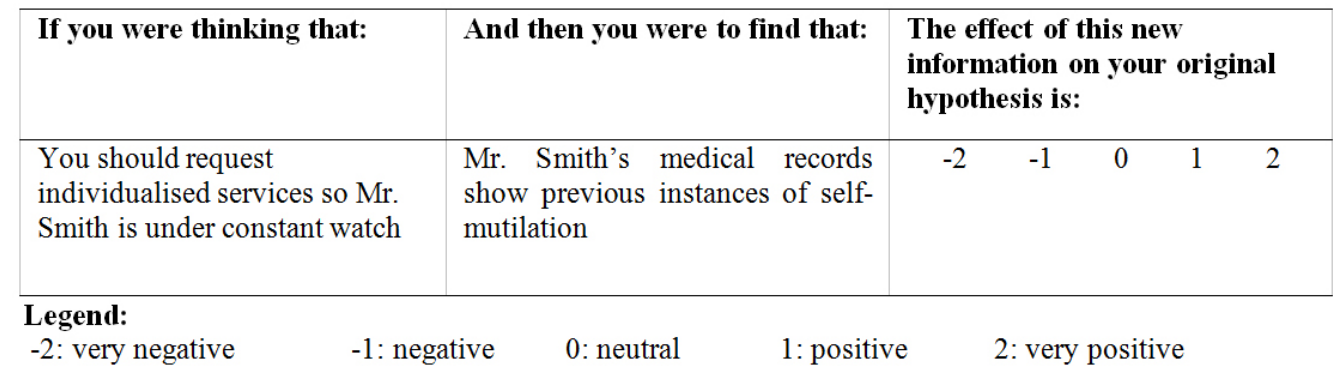

Figure 2. Example of a SCT scenario with one questioned item

The majority of the studies reviewed in nursing focus on the development of an instrument to measure clinical reasoning in nursing and its psychometric properties. In almost all cases, the studies show that the SCT reliably assesses clinical reasoning in addition to distinguishing between participants' levels of expertise. ${ }^{[26,31,33,34,41]}$ These studies generally focused on the assessment of clinical reasoning in nursing, with a particular interest in the human caring dimension ${ }^{[26,41]}$ and nursing management, ${ }^{[30]}$ in the context of paediatrics ${ }^{[34]}$ or clinical deterioration ${ }^{[31]}$ and faced with pharmacotherapy in a geriatric population. ${ }^{[33]}$ The psychometric properties show, for the most part, the validity of the SCT construct, marked by a statistically linear progression of the scores between groups with different levels of expertise. This validity corroborates the theoretical foundations of the measuring instrument and can be explained by the professional experience of experts, who are continuously refining their mental scripts over the years and through their practice. ${ }^{[9-11]}$ However, choosing experts for the reference panel can sometimes raise problems and expose difficulties inherent to creating a standardised and certified assessment. ${ }^{[26,31,33]}$ Moreover, studies where the psychometric properties were more or less significant contained some methodological limitations, including an insufficient number of clinical scenarios on the test, writing which needed to be fine-tuned, and an inadequate period of time allotted to complete the test. ${ }^{[33-35]}$

\subsection{Using the script concordance perspective in nursing education}

The SCT has not been used solely for the purpose of assessing clinical reasoning in nursing, but also as a tool to support and monitor learning. For example, some studies tried to detect the cognitive strategies deployed by different groups of nurses and nursing students ${ }^{[25]}$ and develop a cognitive learning model of clinical nursing reasoning. ${ }^{[5]}$ These two studies used a SCT previously validated in another study ${ }^{[26]}$ as a data collection tool. Participants in the study were called on to verbalise their responses. The study by Dumont, Loye and Goudreau (2015) ${ }^{[25]}$ explored the possibility of using SCT items as a tool to assess students' clinical rea- 
soning. The findings of this study highlight the differences between students, novices, and experts with regard to the cognitive strategies used. One example includes a delayed onset of the formulation of clinical hypotheses by students during the developmental stages of clinical reasoning, an observation also made by Goudreau, Boyer and Létourneau (2014) ${ }^{[5]}$ The conclusions of Dumont, Loye and Goudreau $(2015)^{[25]}$ suggest the potential usefulness of the SCT to evaluate the strengths and weaknesses of students in order to remedy difficulties related to clinical reasoning. ${ }^{[25]}$ In order to better grasp the developmental stages of clinical reasoning, Goudreau, Boyer and Létourneau (2014) ${ }^{[5]}$ developed a cognitive learning model of this competency. Based on findings that rely on empirical research, a cognitive model identifying the developmental stages of the competences from the beginning of their development to the deployment of the expertise was formulated. ${ }^{[42,43]}$ In line with the study by Dumont, Loye and Goudreau (2015), ${ }^{[25]}$ a SCT was used as a data collection tool, with participants in the study voicing their responses out loud. Thus, script concordance helps determine the level of development of the competency and provides proper support to students at critical stages of the development of the competency. ${ }^{[5]}$

The descriptive comparative study conducted by Tapaneeyakorn et al. (2016) ${ }^{[37]}$ distinguished the level of development of clinical reasoning in nursing through the use of a SCT administered to students at different stages of their education. Those that were nearing the end of their studies obtained a better score during the assessment of their clinical reasoning in nursing. For their part, Sadhuwong, Koraneekij and Natakuatoong (2016) ${ }^{[36]}$ documented the effectiveness of an online teaching strategy with nursing students. Following the use of the teaching strategy, the study demonstrated a statistically significant improvement of clinical reasoning in nursing, also measured using the SCT. The teaching strategy used in this study relies on the same theoretical foundations as the SCT, specifically, situated cognitive learning where the student is placed in a real-world situation while benefitting from retroaction regarding the concordance of their reasoning with that of experts in the field. ${ }^{[36]}$ In another study, the SCT scenarios led to the formulation of a relevant teaching strategy for the detection of episodes of delirium by nurses working in an intensive care unit. ${ }^{[32]}$ Even though this study does not target students, it nevertheless demonstrates a relevant use of the SCT in a context of continuing professional development.

\section{DISCUSSION}

The studies examined highlighted the contribution of script theory to the understanding of the clinical reasoning pro- cess in nursing, but also the potential contribution of script concordance for the development of this competency during training.

\subsection{The contribution of script theory to the development of knowledge and clinical reasoning in nursing}

In nursing, scripts are accessed through the activation and use of developed networks of organized knowledge, where the potential to identify the treatment while treating the patient is solidified. The contextual, experiential and significant contingencies and characteristics of a health care intervention are intrinsically linked with the reasoning process of nurses and shape the intentional action of providing competent, human care. Clinical nursing reasoning is contextualized (or situated), ${ }^{[1]}$ so cognitive strategies favourable to the resolution of a problem are used. ${ }^{[4,5,18,44]}$ Through situational awareness, a sensitive or perceptive competency, nurses can identify the key elements of a care situation and fuel the critical thinking process. This situated cognition enhances the recognition of key elements associated with the contingencies of a care situation, without necessarily establishing it as a de facto occurrence or linking it to an immutable or arrested causality. Thus, the complexity of everyday nursing practice multiplies the stimuli stemming from the environmental context. This characteristic of context can cause cognitive overload and create dissonance between the various elements of knowledge or scripts activated by the nurses ${ }^{[28,45]}$ or lead to the carrying out of clinical tasks without critical appropriation of the routines and treatment protocols. ${ }^{[5,46]}$ In this regard, the delayed onset of the cognitive strategies that generate hypotheses in students ${ }^{[5,46]}$ is an inherent component underlying clinical reasoning in nursing and merits further attention. Hence, it appears essential to seek and support educational activities that promote the development of knowledge, and subsequently of clinical reasoning in nursing, modeled on scripts that are outlined and configured through regular use in order to be retrieved at a later date, when relevant to the practice. ${ }^{[47]}$ In sum, it is important to "train reasoning in order to better apply it".

\subsection{The implications of script theory and script concor- dance for nursing education}

Script concordance sheds light on the importance of developing innovative teaching practices through its tendency to contextualize and multiply learning in real-world situations. Moreover, it identifies the degree of development of the competency in students through comparison with experts who have also completed the SCT. These experts act as role models during the activation of contextualized clinical nursing reasoning and during the relevant and warranted use of nursing knowledge. However, relying on a learning model of 
the thought process of experts is not a practice exclusive to SCTs. For example, other teaching strategies, such as case studies, problem-based learning, schematisation, explanation exercises, as well as an early, supervised, and continuous practice in clinical settings, ${ }^{[47]}$ also rely on this model. In this vein, the script concordance perspective constitutes an innovation with regard to the application of these strategies: it enlists metacognitive thought processes in both students and experts. This paper is interested in the way the knowledge is processed in real-world and uncertain contexts that are part of professional practice. Learning cannot be limited to knowledge, but must also include the acquisition of reasoning skills: ${ }^{[48]}$ reflective practice is at the heart of the application of these teaching opportunities. Associated with an acute awareness of professional practice, reflective practice enlists an iteration of thinking for and through the action of treatment. ${ }^{[49-52]}$ Yet, we are aware that verbal explanations do not always reflect the exact thought process, and that the activation of scripts remains a somewhat enigmatic phenomena. ${ }^{[4]}$ But this effort to articulate knowledge and apply it presents a fertile ground to increase students' situational awareness and honed reflective skills, engaging a dialogue between students and experts as well as a potential model of reasoning in experts (see Figure 2). The aim is for students to develop contextualised (or situated) and important clinical reasoning. This structured, detailed comparison allows students to assess whether the cognitive strategies used are in line with those of experts in a given contextualized clinical situation. This awareness engages students in a reflective process, encouraging them to take charge of everything learned. ${ }^{[53]}$ Thus, educational training strategies based on script concordance provide pedagogical support to the development of clinical reasoning in real-world situations of clinical practice.

Script concordance, which optimises situated clinical reasoning, ties in with the socio-cognitive perspective of cognitive apprenticeship, ${ }^{[54-58]}$ through the use of role models to guide the development of knowledge and clinical reasoning in nursing. This approach does not imply the imitation of experts' cognitive activities, but rather offers a dialogic relationship during the process of nursing knowledge development: a healthy, constructive, and diversified confrontation of mental representations schemas. For example, the use of SCTs as training tools provides training materials adapted to the professional reality for these pedagogical activities. Through the assessment of clinical reasoning, the SCT explores the ability to generate hypotheses and choose interventions in real-world situations in nursing practice. ${ }^{[26]}$ It allows, among other things, for the targeting of conditional and situational elements that can influence the formulated hypotheses and assess their concordance with those of experts in the field. ${ }^{[15]}$ In this regard, exploring teaching strategies based on script concordance leads us to believe in its potential to engage and optimise the repertoire and wealth of knowledge (scripts) developed by students, particularly through planned metacognitive exercises. This pedagogical intent also aims to implement potential remedial measures during training, ${ }^{[25]}$ associated with the cognitive strategies students do or do not use.

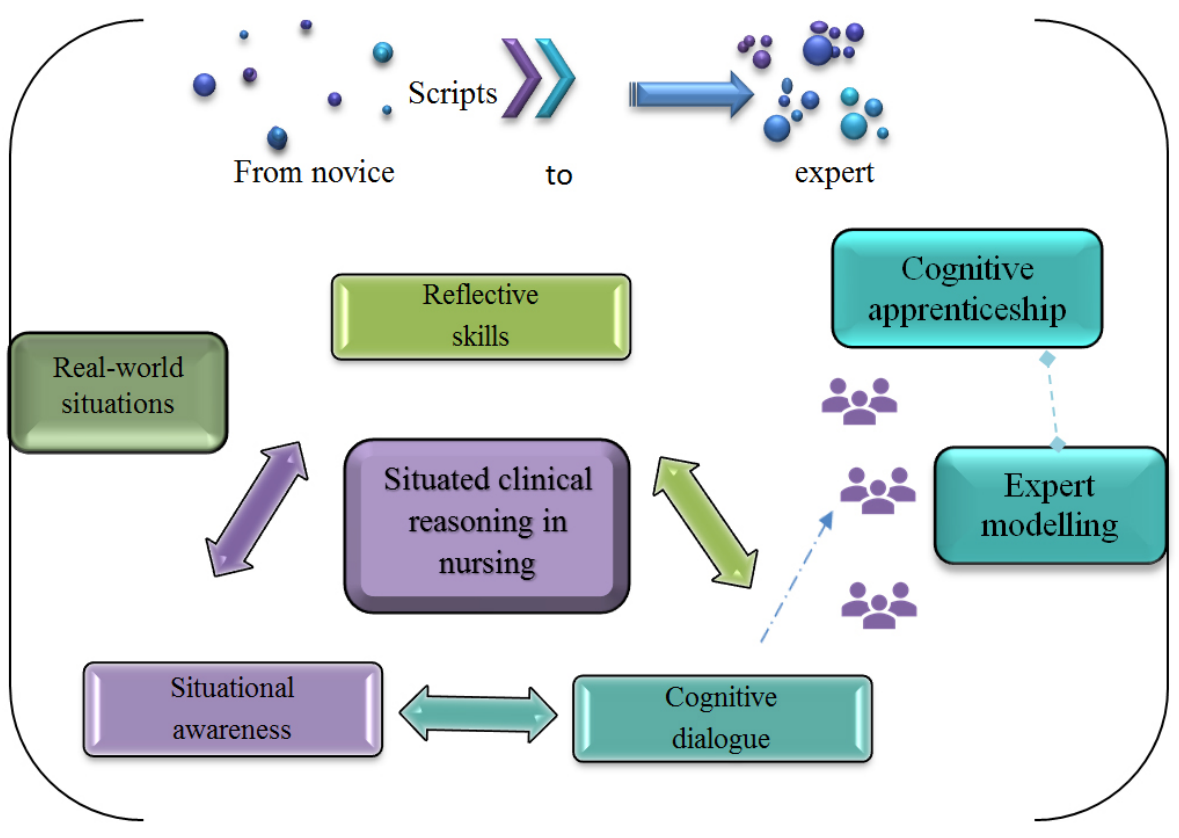

Figure 3. Development of knowledge and clinical reasoning in nursing through script concordance 


\subsection{Implications of script theory or script concordance for research in nursing}

In nursing, studies mostly focus on the development of SCTs and the analysis of their psychometric properties, but little interest is paid to their pedagogical implications. Thus, future studies conducted should focus on gathering empirical data on the application of teaching strategies based on script concordance in initial or continued nursing training. In this regard, recent research in medicine has investigated the relevance and feasibility of educational activities integrating the SCT as a training tool. ${ }^{[59-62]}$ These script concordance activities aim to make experts' tacit knowledge explicit by providing a detailed explanation of their thought processes as they are completing the SCT. Thus, once they have completed the SCT, students will receive feedback that includes the usual quantitative results obtained on this test and the thought processes of the experts. These activities have been operationalized through the use of an online platform, ${ }^{[59,60,63]}$ discussion groups, ${ }^{[61]}$ or thoughts written down once the SCT was completed. ${ }^{[62]}$ These studies highlight the students' appreciation of this teaching strategy, in particular because of its relevance in combining learned knowledge and realworld situations encountered in practice. This appreciation also enables the self-regulation of students' way of thinking through feedback and the explanation of experts' thought processes. However, the impacts of this teaching strategy remain poorly documented in both the medical literature as well as the body of knowledge in nursing. Thus, how can script concordance enable the implementation of strategies to remediate difficulties with regard to clinical reasoning in nursing? How does it generate particular learning needs? How does clinical reasoning evolve through the combination of different teaching strategies that activate scripts? How is the role of expert professor and reflective role model shaped? And especially, how can these teaching strategies based on script concordance be implemented in order to integrate them in a pertinent way into training? These questions provide possible avenues for further research to develop knowledge in nursing education.

\subsection{Strengths and limitations of the literature review}

This literature review enabled an original and diversified consultation of the literature on the development of clinical reasoning in nursing through an educational perspective centered on the formulation and the concordance of scripts. The theoretical perspective examined in this paper, which plays a prominent role in integrative literature reviews, ushers in a theoretical framework, ${ }^{[22,23]}$ and consequently a pertinent formulation of the teaching strategies to implement. However, the scope was limited as only studies in French and English were consulted, and other studies or papers on pedagogical practices on this subject may have been omitted. The review of gray literature was also more difficult to target through the usual database searches, despite the availability of this literature on the CPASS site, a networking site specifically dedicated to research on SCTs. Moreover, the restricted time allotted for the documentation search and the available resources may have limited the extent of the data we obtained on the subject.

\section{Conclusion}

The perspective of script concordance allows a foreseeable innovative formulation of practices favourable to the development of clinical reasoning in nursing. Moreover, this perspective presents a solid theoretical foundation to support the development of this competency during initial nursing education and continuing professional development. Further research should focus on validating the teaching opportunities of this perspective, and thus developing a nursing pedagogy adapted to the contingencies of current practice.

\section{ACKNOWLEDGEMENTS}

This work was supported by Équipe Futur, which is funded by the Fonds de recherche du Québec - Société et culture (FRQSC).

\section{CONFlicts OF INTEREST Disclosure}

The authors declare that they have no competing interest.

\section{REFERENCES}

[1] Benner P, Sutphen M, Leonard V, et al. Educating nurses: a call for radical transformation. San Francisco, CA: Jossey-Bass; 2010.

[2] Levett-Jones T, Hoffman K, Dempsey J, et al. The 'five rights' of clinical reasoning: an educational model to enhance nursing strudent's ability to identify and manage clinical 'at risk' patients. Nurse Education Today. 2010; 30(6): 515-520. PMid: 19948370 http://doi.org/10.1016/j.nedt.2009.10.020

[3] Alfaro-LeFevre R. Critical thinking and clinical judgment: A practi- cal approach to outcome-focused thinking. 5 ed. St-Louis: Elsevier; 2013.

[4] Simmons B. Clinical reasoning: concept analysis. Journal of Advanced Nursing. 2010; 66(5): 1151-1158. PMid: 20337790 http: //doi.org/10.1111/j.1365-2648.2010.05262.x

[5] Goudreau J, Boyer L, Létourneau D. Clinical Nursing Reasoning in Nursing Practice: A Cognitive Learning Model based on a Think Aloud Methodology. Quality Advancement in Nursing Education - Avancées en formation infirmière. 2014; 1(1): 1-18. 
http://doi.org/10.17483/2368-6669.1009

[6] Abelson RP. Concepts for representing mundane reality in plans, In D.G. Bobrow and A. Collins, (Eds.). Representation and understanding: Studies in cognitive science (pp. 273-309). New-York: Academic Press; 1975.

[7] Schank R, Abelson R. Script, Plans, Goals and Understanding: An Inquiry into Human Knowledge Structures. Hillsdale, New Jersey: Lawrence Erlbaum Associates. 1977.

[8] Frith C. Making up the mind: How the brain creates our mental world. Malden, M. A: Blackwell Publishing; 2007.

[9] Custers EJ. Thirty years of illness scripts: Theoretical origins and practical applications. Medical Teacher. 2015; 37(5): 457-462. PMid: 25180878 http://doi.org/10.3109/0142159X . 2014.956052

[10] Charlin B, Tardif J, Boshuizen HPA. Scripts and medical diagnostic knowledge: Theory and applications for clinical reasoning instruction and research. Academic Medecine. 2000; 75(2): 182-190. PMid: 10693854 http: //doi .org/10.1097/00001888-200002000-0 0020

[11] Schmidt HG, Norman GR, Boshuizen HPA. A cognitive perspective on medical expertise. Theory and implications. Academic Medecine. 1990; 65(10): 611-621. PMid: 2261032 http://doi .org/10.109 7/00001888-199010000-00001

[12] Bordage G. Elaborated knowledge: a key to successful diagnostic thinking. Academic Medicine. 1994; 69(11): 883-885. PMid: 7945684 http://doi.org/10.1097/00001888-199411000-0 0004

[13] Nendaz M, Charlin B, Leblanc V, et al. Le raisonnement clinique : données issues de la recherche et implications pour l'enseignement. Pédagogie Médicale. 2005; 6(4): 235-254. http://doi .org/10.1 051/pmed : 2005028

[14] Charlin B, Boshuizen HPA, Custers EJ, et al. Scripts and clinical reasoning. Medical Education. 2007; 41: 1178-1184. PMid: 18045370 http://doi.org/10.1111/j.1365-2923.2007.02924.x

[15] Charlin B, Fernandez N. Formation par concordance (FpC). Préparer en ligne à la complexité et l'incertitude de la pratique. In 7th International Francophone Forum for Health Sciences Pedagogy. Québec, Canada. 2016

[16] Charlin B, Lubarsky S, Millette B, et al. Clinical reasoning processes: unravelling complexity through graphical representation. Medical Education. 2012; 46(5): 454-463. PMid: 22515753 http: //doi.org/10.1111/j.1365-2923.2012.04242.x

[17] Faucher C, Pelacia T, Nandaz M, et al. Un professionnel de la santé qui résout efficacement les problèmes : le raisonnement clinique, In $\mathrm{T}$. Pelaccia, (Eds.). Comment (mieux) former et évaluer les étudiants en médecine et en sciences de la santé? (pp. 33-44). Bruxelles, Belgique: De Boeck. 2016

[18] Fonteyn ME, Ritter BJ. Clinical reasoning in nursing, In J. Higgs, M.A. Jones, S. Loftus, and N. Chirstensen, (Eds.). Clinical reasoning in the health professions. Oxford, United Kingdom: ButterworthHeinemann; 2008. 235-244 p.

[19] Higgs J, Jones M, Loftus S, et al. Clinical reasoning in the health professions. 3è ed. Oxford, United Kingdom: Butterworth-Heinemann; 2008.

[20] Whittemore R, Knafl K. The integrative review: updated methodology. Journal of Advanced Nursing. 2005; 52(5): 546-553. http: //doi.org/10.1111/j.1365-2648.2005.03621.x

[21] Broome ME. Integrative literature reviews for the development of concepts, In B.L. Rogers and K.A. Knafl, (Eds.). Concept development in nursing: foundations, techniques and applications. Philadelphia: WB Saunders Company; 2000. 231-250 p.

Published by Sciedu Press
[22] Torraco RJ. Writing integrative literature reviews: Guidelines and examples. Human Resource Development Review. 2005; 4(3): 356-367. http://doi.org/10.1177/1534484305278283

[23] Torraco RJ. Writing Integrative Literature Reviews: Using the Past and Present to Explore the Future. Human Resource Development Review. 2016; 15(4): 404-428. http://doi.org/10.1177/1534 484316671606

[24] Kirkevold M. Integrative nursing research—an important strategy to further the development of nursing science and nursing practice. Journal of Advanced Nursing. 1997; 25(5): 977-984. PMid: $9147203 \mathrm{ht}$ tp://doi.org/10.1046/j.1365-2648.1997.1997025977.x

[25] Dumont K, Loye N, Goudreau J. Le potentiel diagnostique des questions d'un test de concordance de scripts pour évaluer le raisonnement clinique infirmier. Pédagogie Médicale. 2015; 16(1): 49-64. http://doi.org/10.1051/pmed/2015012

[26] Deschênes MF, Charlin B, Gagnon R, et al. Use of a Script Concordance Test to Assess Development of Clinical Reasoning in Nursing Students. Journal of Nursing Education. 2011; 50(7): 381-387. PMid: 21449528 http://doi.org/10.3928/01484834-20110 331-03

[27] Fonteyn ME. Thinking strategies for nursing practice. Philadelphia, PA: Lippincott. 1998.

[28] Greenwood J, Sullivan J, Spence K, et al. Nursing scripts and the organizational influences on critical thinking: Report of a study of neonatal nursing' clinical reasoning. Journal of Advanced Nursing. 2000; 31: 1106-1114. PMid: 10840244 http://doi.org/10.104 $6 / j .1365-2648.2000 .01378 . x$

[29] Offredy M, Meerabeau E. The use of 'think aloud'technique, information processing theory and schema theory to explain decision-making processes of general practitioners and nurse practitioners using patient scenarios. Primary Health Care Research and Development. 2005; 6(1): 46-59. http://doi.org/10.1191/1463423605pc22 8 oa

[30] Borges, PFB. Script Concordance Test: a proposal for evaluation of the management of nursing reasoning in uncertain situations (Master's thesis). Botucatu, Portugal: Botucatu Medical School, Universida de Estadual Paulista "Julio de Mesquita Filho". 2016.

[31] Côté S, Tanguay A, Gagnon R, et al. Élaboration et validation d'un test de concordance de script pour évaluer le raisonnement clinique des infirmières en contexte de détérioration clinique. Pédagogie Médicale. 2014; 15: 7-20. http://doi .org/10.1051/pmed/2014004

[32] Devlin JW, Marquis F, Riker RR, et al. Combined didactic and scenario-based education improves the ability of intensive care unit staff to recognize delirium at the bedside. Critical Care. 2008. PMid:18291021 http://doi.org/10.1186/cc6793

[33] Gilbert A. Élaboration et évaluation d'un test de concordance de script pour mesurer le raisonnement clinique infirmier relatif à l'usage optimal des médicaments en centre d'hébergement (Unpublished Master's thesis). Sherbrooke, Canada: Université de Sherbrooke. 2015.

[34] Latreille ME. Évaluation du raisonnement clinique d'étudiantes et d'infirmières dans le domaine de la pédiatrie à l'aide d'un test de concordance de script (Unpublished Master's thesis). Ottawa, Canada: Université d'Ottawa. 2012.

[35] Pintz C. Assessment of diagnostic reasoning with standardized patients: Testing the reliability and validity of the diagnostic reasoning assessment. (Doctoral thesis). Baltimore, United States: University of Maryland. 2006.

[36] Sadhuwong K, Koraneekij P, Natakuatoong O. Effects of a blended learning model integrating situated multimedia lessons and cognitive apprenticeship method on the clinical reasoning skills of nursing students. Journal of Health Research. 2016; 30(6): 421-431. 
[37] Tapaneeyakorn W, Kosolchuenvijit J, Anonrath K, et al. Factors Affecting Clinical Reasoning of Nursing Students at Boromarajonani College of Nursing Bangkok. Journal of Health Science Research. 2016; 10(1): 70-77.

[38] Charlin B. Standardized assessment of ill-defined clinical problems: the script concordance test (Doctoral thesis). Maastricht, The Netherlands: Maastricht University. 2002.

[39] Charlin B, Gagnon R, Sibert L, et al. Le test de concordance de script, un instrument d'évaluation du raisonnement clinique. Pédagogie Médicale. 2002; 3(3): 135-144. http://doi .org/10.1051/pmed: 2002022

[40] Charlin B, Roy L, Brailovsky C, et al. The Script Concordance test: a tool to assess the reflective clinician. Teaching and Learning in Medicine. 2000; 12(4): 189-195. PMid: 11273368 http: //doi.org/10.1207/s15328015tlm1204_5

[41] Dawson TE, Comer L, Kossick MA, et al. Can script concordance testing used in nursing education to accurately assess clinical reasoning skills? Journal of Nursing Education. 2014; 53(5): 281-286. PMid: 24641082 http://doi.org/10.3928/01484834-20140 321-03

[42] National Research Council. Knowing what students know: The science and design of educational assessment. Washington, DC: National Academies Press. 2001.

[43] Tardif J. L'évaluation des compétences. Documenter le parcours de développement. Montréal, Québec: Chenelière Éducation. 2006.

[44] Banning M. Clinical reasoning and its application to nursing: concepts and research studies. Nurse Education in Practice. 2008; 8(3): 177-183. PMid:17869587 http://doi.org/10.1016/j.nepr.2 007.06 .004

[45] Greenwood J. Critical thinking and nursing scripts: the case for the development of both. Journal of Advanced Nursing. 2000; 31(2): 428436. PMid: 10672102 http://doi .org/10.1046/j.1365-2648. 2000.01283.x

[46] Létourneau D, Boyer L, Goudreau G. Cognitive model of learning clinical nursing reasoning: educational issues. In 6th World Congress of the International Secretariat of Nurses of the Francophone Space (SIIDIEF). Montreal, Canada. 2015.

[47] Lubarsky S, Dory V, Audétat MC, et al. Using script theory to cultivate illness script formation and clinical reasoning in health professions education. Canadian Medical Education Journal. 2015; 6: e61-e70. PMid: 27004079

[48] Pelaccia T, Dory V. Comment aider les étudiants en sciences de la santé à développer leur intuition ? In 7th International Francophone Forum for Health Sciences Pedagogy. Québec, Canada. 2016.

[49] Argyris C, Schon D. Theory in Practice: Increasing Profesionnal Effectiveness. San Francisco, CA: Jossey-Bass. 1992/1974.

[50] Schon DA. The reflective practioner: How professionals think in action. New York, NY: Basic Books. 1983.

[51] Schon D. Educating the reflective practitioner. New-York: JosseyBass. 1987.
[52] Dewey J. How we think: A restatement of the relation of reflective thinking to the educational process. Boston, DC: Health and Compagny. 1933.

[53] Charlin B, Fernandez N. Préparer et animer une formation par concordance, In T. Pelaccia, (Eds.). Comment (mieux) former et évaluer les étudiants en médecine et en sciences de la santé? (pp. 325-340). Bruxelles, Belgique: De Boeck Supérieur. 2016.

[54] Collins A, Brown JS, Holum A. Cognitive apprenticeship: Making thinking visible. American Educator. 1991; 15(3): 6-11.

[55] Bédard D, Frenay M, Turgeon J, et al. Les fondements des dispositifs pédagogiques visant à favoriser le transfert de connaissances: les perspectives de l'apprentissage et de l'enseignement contextualisés authentiques. Res Academica. 2000; 18(1-2): 21-46.

[56] Vanpee D, Frenay M, Godin V, et al. Ce que la perspective de l'apprentissage et de l'enseignement contextualisés authentiques peut apporter pour optimaliser la qualité pédagogique des stages d'externat. Pédagogie Médicale. 2010; 10(4): 253-266. https : //doi.org/10.1051/pmed/20090330

[57] Collins A, Brown JS, Newman SE. Cognitive Apprenticeship: Teaching the Crafts of Reading, Writing, and Mathematics, In L.B. Resnick, (Eds.). Knowing, Learning and Instruction. Hillsdale, N. J: Lawrence Erlbaum Associates; 1989. 453-494 p.

[58] Frenay M, Bédard D. Des dispositifs de formation universitaire s'inscrivant dans la perspective d'un apprentissage et d'un enseignement contextualisé pour favoriser la construction de connaissances et leur transfert, In A. Presseau and M. Frenay, (Eds.). Le transfert des apprentissages: comprendre pour mieux intervenir. Québec: Les Presses de 1'Université Laval; 2004. 241-268 p.

[59] Fernandez N, Foucault A, Dubé S, et al. Learning-by-Concordance $(\mathrm{LbC})$ : introducing undergraduate students to the complexity and uncertainty of clinical practice. Canadian Medical Education Journal. 2016; 7(2): 104-113. PMid: 28344697

[60] Foucault A, Dubé S, Fernandez N, et al. Learning medical professionalism with the online concordance-of-judgment learning tool (CJLT): A pilot study. Med Teach. 2015; 37(10): 955-960. PMid: 25336258 http://doi.org/10.3109/0142159X .2014.970986

[61] Compère V, Abily J, Moriceau J, et al. Residents in tutored practice exchange groups have better medical reasoning as measured by script concordance test: a controlled, nonrandomized study. Journal of Clinical Anesthesia. 2016; 32: 236-241. PMid: 27290981 http://doi.org/10.1016/j.jclinane.2016.03.012

[62] Power A, Lemay JF, Cooke S. Justify your Answer: The Role of Written Think Aloud in Script Concordance Testing. Teaching and Learning in Medicine. 2016; 29(1): 1-9. PMid: 27662118 http://doi .org/10.1080/10401334.2016.1217778

[63] Hayward J, Cheung A, Velji A, et al. Script-theory virtual case: A novel tool for education and research. Medical Teacher. 2016: 19. PMid: 27102980 http://doi.org/10.3109/0142159x.201 6.1170776 